\title{
Pengaruh Fraksi Berat Serat Waru terhadap Sifat Mekanik Kampas Rem Kereta Api Komposit Non Asbestos
}

\author{
Bayu Prasetya dan Mochamad Zainuri \\ Departemen Fisika, Fakultas Matematika dan Ilmu Pengetahuan Alam, Institut Teknologi Sepuluh Nopember \\ Jl. Arief Rahman Hakim, Surabaya 60111 Indonesia \\ e-mail: zainuri@physics.its.ac.id
}

\begin{abstract}
Abstrak-Kampas rem berbahan asbestos telah diketahui memiliki beberapa kelemahan. Bahan komposit non asbestos saat ini mulai banyak digunakan karena sifatnya yang ramah lingkungan, murah, dan mudah diperoleh. Penelitian ini bertujuan untuk membuat kampas rem kereta api berbahan komposit non asbestos dengan penguat serat waru dan untuk mengetahui pengaruh fraksi berat serat waru terhadap sifat mekanik kampas rem. Variasi fraksi berat serat waru yang digunakan adalah $4 \%, 6 \%, 8 \%, 10 \%$, dan $12 \%$. Pengujian sifat mekanik yang dilakukan meliputi kekerasan, densitas, koefisien gesek, dan keausan. Hasil penelitian menunjukkan bahwa fraksi berat serat waru memengaruhi sifat mekanik kampas rem komposit non asbestos. Terjadi penurunan nilai kekerasan dan densitas pada sampel dengan fraksi berat serat waru yang semakin besar. Jumlah fraksi berat serat waru yang semakin besar juga meningkatkan nilai keausan dan koefisien gesek.
\end{abstract}

Kata Kunci-Kampas rem, komposit, non asbestos, serat waru.

\section{PENDAHULUAN}

$\mathrm{T}$ EKNOLOGI kereta api telah berkembang sangat pesat. Salah satu bagian penting dari kereta api adalah sistem pengereman. Sistem pengereman pada kereta api terdiri dari beberapa komponen yaitu kampas rem, cakram, dan sistem hidrolik. Kampas rem konvensional biasanya terbuat dari bahan asbestos. Debu asbestos sangat berbahaya bagi kesehatan pernafasan. Oleh karena itu saat ini penggunaan kampas rem berbahan asbestos mulai digantikan dengan bahan yang lebih aman. Bahan dari alam yang banyak terdapat di Indonesia dapat menjadi alternatif pengganti bahan asbestos. Salah satu bahan alam yang mudah dijumpai adalah serat waru. Penelitian ini bertujuan untuk membuat kampas rem kereta api berbahan komposit dengan penguat serat waru.

Sistem pengereman adalah suatu sistem yang berfungsi menghambat atau menghentikan laju kendaraan. Sistem pengereman memiliki peran sangat penting dalam bidang otomotif karena bertanggung jawab terhadap keselamatan pengendara kendaraan. Untuk memastikan sistem pengereman pada kendaraan dapat berfungsi dengan baik dan mampu menjamin keselamatan pengendara, maka dibutuhkan suatu standar yang baku [1].

Bagian penting dari sistem pengereman adalah kampas rem. Kualitas kampas rem dipengaruhi oleh beberapa faktor yaitu komposisi bahan, jenis bahan, dan kekerasan bahan. Kampas rem berbahan dasar asbestos pada keadaan basah akan mengalami penurunan kemampuan pengereman. Selain itu bahan asbestos hanya mampu bertahan pada suhu $200^{\circ} \mathrm{C}$ dan akan mengalami fading (blong) di atas suhu tersebut. Kampas rem berbahan asbestos memiliki harga murah. Kekurangan dari bahan asbestos adalah debu hasil gesekannya dapat menyebabkan kanker jika terhirup [2].

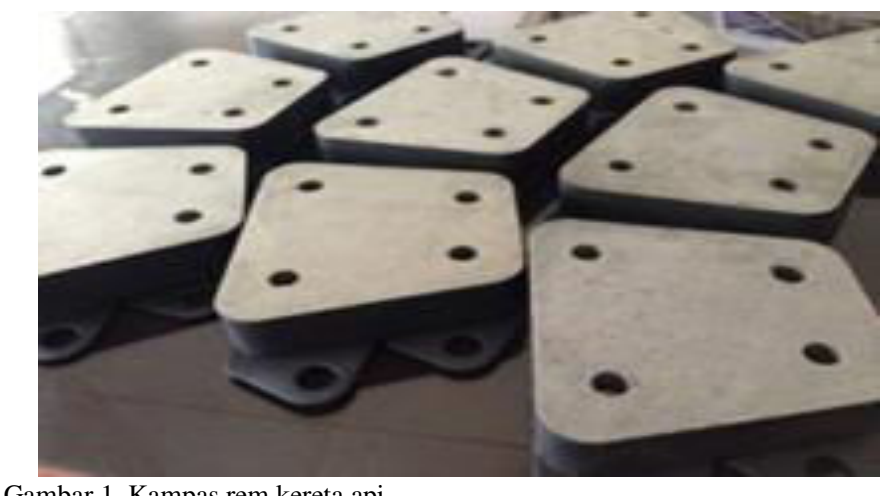

Gambar 1. Kampas rem kereta api.

Komposit adalah dua atau lebih material yang dikombinasikan sedemikian rupa sehingga memungkinkan untuk membuat material baru yang lebih baik. Komposit memanfaatkan keunggulan material penyusun dan meminimalkan sampai batas tertentu efek dari kekurangan mereka [3]. Bahan komposit tersusun atas dua fase yaitu matriks dan pengisi (filler). Matriks adalah fase yang berperan sebagai pengikat, sedangkan pengisi berfungsi sebagai penguat [4].

Serat alami diketahui telah sejak lama digunakan oleh manusia untuk berbagai keperluan. Jumlah serat alami sangat melimpah di alam dan dapat diperoleh dengan mudah. Serat alami sangat banyak jenisnya dan dapat diperoleh dari beberapa bagian tanaman seperti daun, buat, sabut, batang, dan rumput [5].

Serat alami dapat terurai dengan mudah di alam sehingga tidak menimbulkan pencemaran. Harga serat alami juga lebih murah dibandingkan dengan serat sintetis. Namun serat alami memiliki kekurangan yaitu kualitasnya yang tidak seragam. Selain itu serat alami juga memiliki ketahanan rendah terhadap panas [6].

Bahan komposit berpenguat serat biasanya menggunakan fiber glass sebagai penguatnya. Fiber glass banyak digunakan karena memiliki kekuatan yang cukup baik. Namun karena fiber glass terbuat dari bahan berbasis fosil yang sulit terurai 
di alam, penggunaannya saat ini mulai berkurang. Sebagai penggantinya sekarang banyak bahan komposit yang menggunakan penguat serat alami seperti jerami, sabut, rami, bambu, dan sebagainya [5].

Waru (Hibiscus tiliaceus) adalah jenis tanaman yang banyak dijumpai di Indonesia [7]. Kulit pohon waru banyak mengandung serat yang dapat diperoleh dengan cara direndam dan dipukul-pukul. Setelah melalui perlakuan perendaman di dalam air selama tujuh hari dan penjemuran di bawah sinar matahari dapat diperoleh serat yang halus. Serat dari pohon waru yang biasa disebut lulup sering dimanfaatkan untuk tali, jaring, dan tas [8].

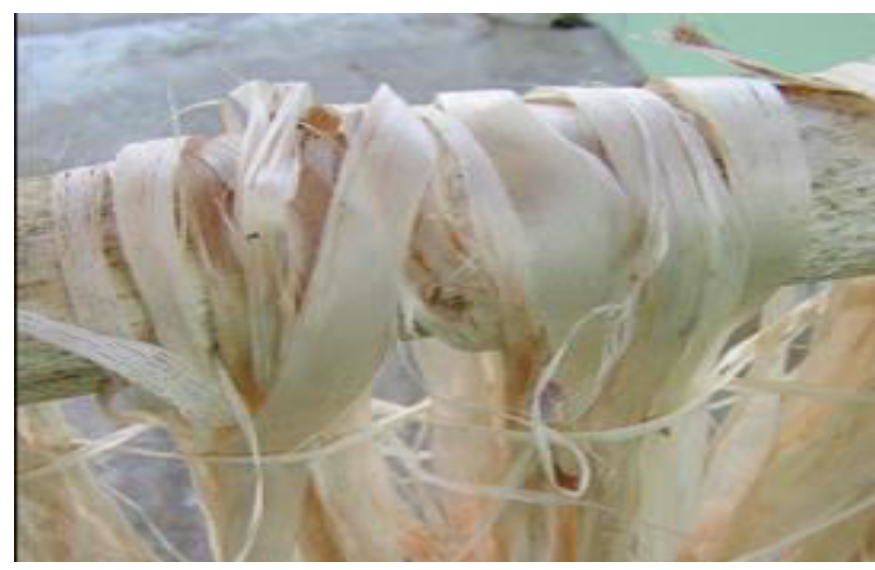

Gambar 2. Serat waru.

Sifat mekanik bahan menunjukkan respon dari suatu bahan terhadap aktivitas mekanik yang dialami oleh bahan tersebut. Menentukan sifat mekanik suatu bahan tentu sangat penting untuk dapat memanfaatkannya dengan baik. Sifat-sifat mekanik yang penting untuk diketahui antara lain kekuatan, kekerasan, kelenturan, dan kekakuan. Untuk mengetahui sifat mekanik suatu bahan perlu dilakukan pengujian sesuai standar [4].

\section{METODE}

\section{A. Alat}

Alat yang digunakan dalam penelitian ini adalah timbangan digital, mixer, mesin press, cetakan, oven listrik, mesin bubut, Microhardness Vickers Tester, set alat uji densitas, beaker glass, gerinda, Tribometer Pin on Disc, dan set alat uji koefisien gesek.

\section{B. Bahan}

Bahan yang digunakan adalah iron serbuk, ceramic fiber, aluminium serbuk, aluminium oxide, serat waru, dan resin.

\section{Langkah Kerja}

Langkah-langkah yang dilakukan dalam penelitian ini adalah:

1. Persiapan bahan.

2. Pembuatan campuran dengan komposisi fraksi serat waru $4 \%, 6 \%, 8 \%, 10 \%$, dan $12 \%$.

3. Pencampuran bahan.

4. Proses pencetakan.
5. Proses kompaksi dengan beban..

6. Proses pemanasan (sintering)

7. Pengujian kekerasan, densitas, keausan, dan koefisien gesek.

8. Analisis data.

9. Penarikan kesimpulan.

\section{Diagram Alir}

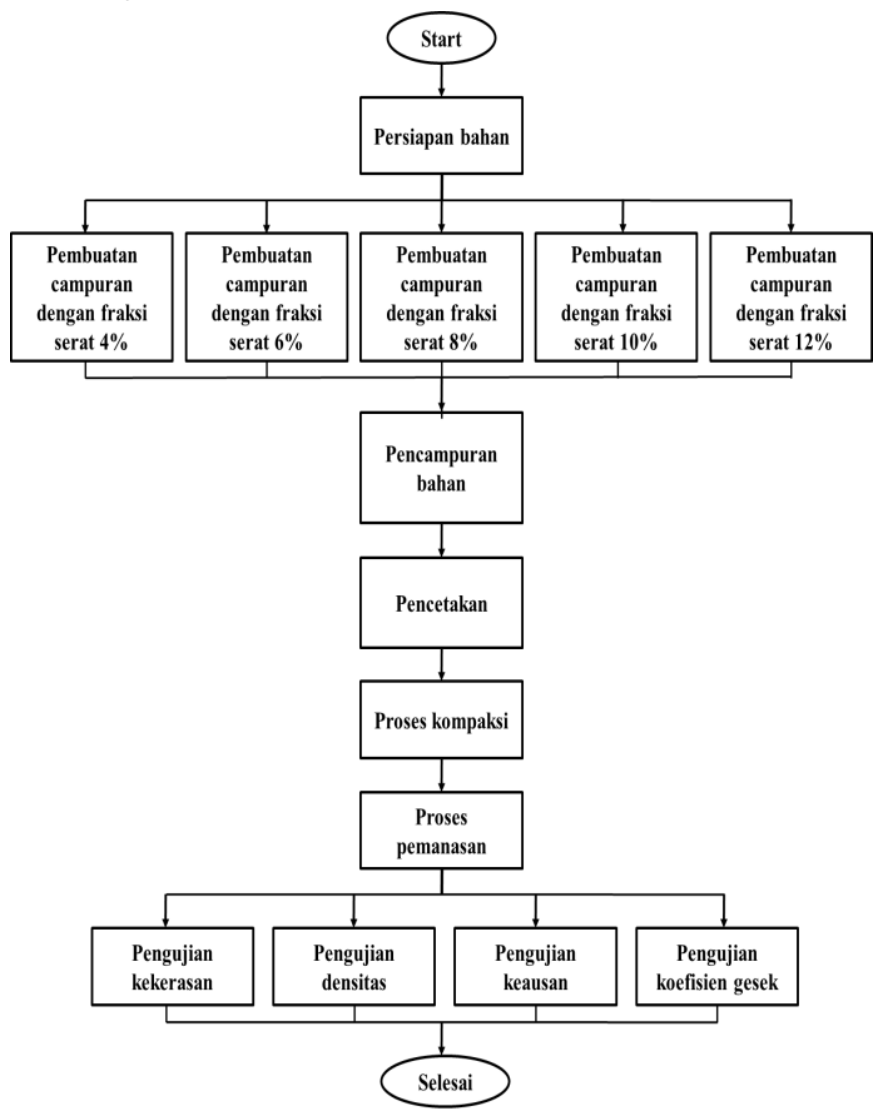

Gambar 3. Diagram alir langkah kerja.

\section{HASIL DAN PEMBAHASAN}

\section{A. Hasil Pengujian Kekerasan}

Hasil pengujian nilai kekerasan sampel dapat dilihat pada tabel berikut

Tabel 1.

Nilai kekerasan semua sampel

\begin{tabular}{ccc}
\hline \hline Fraksi serat waru (\%) & Perlakuan panas $\left({ }^{\circ} \mathrm{C}\right)$ & Kekerasan $(\mathrm{HV})$ \\
\multirow{3}{*}{4} & 25 & 21,70 \\
& 150 & 8,40 \\
& 300 & 6,90 \\
6 & 25 & 21,24 \\
& 150 & 8,86 \\
& 300 & 7,82 \\
8 & 25 & 15,42 \\
& 150 & 9,27 \\
\multirow{2}{*}{10} & 300 & 6,67 \\
& 25 & 14,20 \\
& 150 & 7,68 \\
12 & 300 & 7,16 \\
& 25 & 12,66 \\
& 150 & 5,80 \\
& 300 & 3,92 \\
\hline
\end{tabular}


Dari Tabel 1 dapat diketahui bahwa nilai kekerasan setiap sampel berbeda untuk setiap variasi jumlah fraksi serat waru dan suhu perlakuan panas. Nilai kekerasan yang diperoleh antara 3,92 HV hingga 21,70 HV.

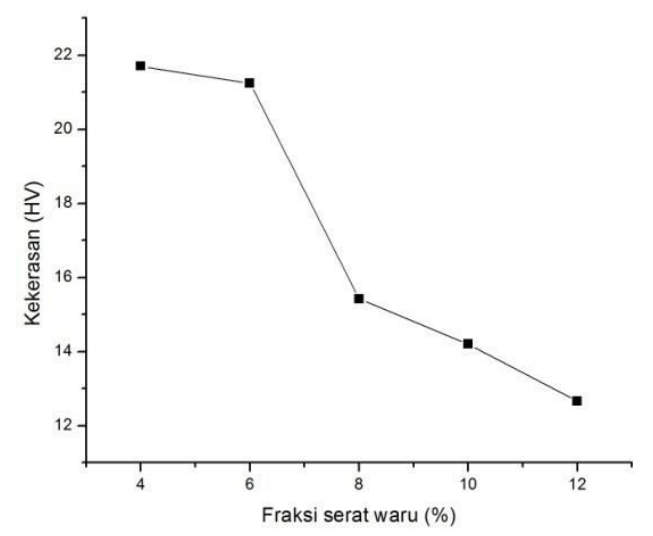

Gambar 4. Grafik hubungan fraksi serat waru terhadap nilai kekerasan pada suhu perlakuan panas $25^{\circ} \mathrm{C}$.

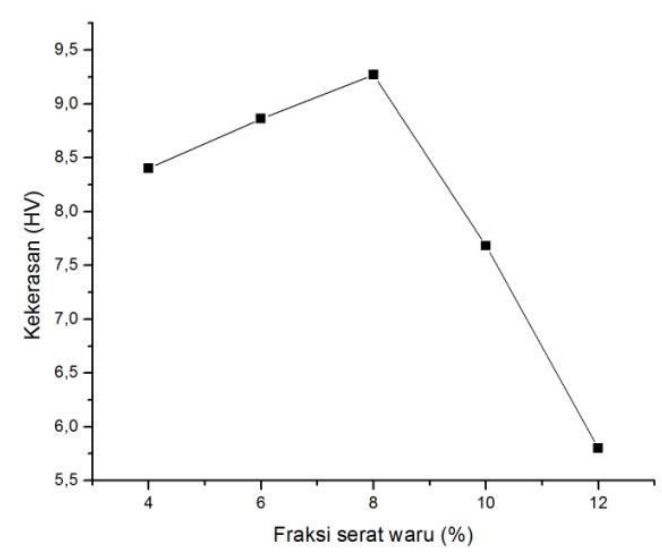

Gambar 5. Grafik hubungan fraksi serat waru terhadap nilai kekerasan pada suhu perlakuan panas $150^{\circ} \mathrm{C}$.

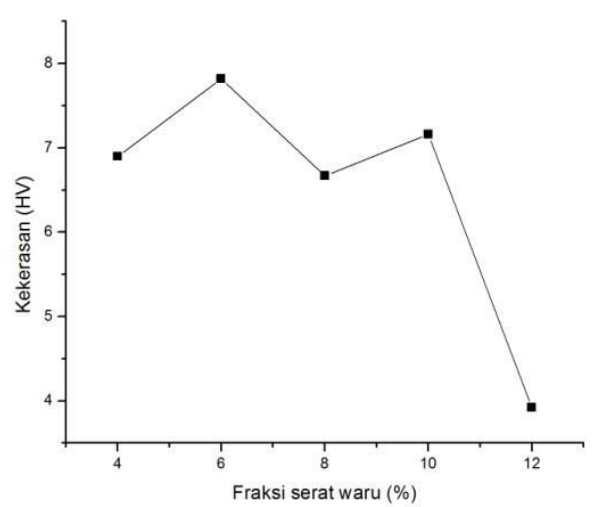

Gambar 6. Grafik hubungan fraksi serat waru terhadap nilai kekerasan pada suhu perlakuan panas $300^{\circ} \mathrm{C}$.

Pada Gambar 4 ditunjukkan grafik hubungan antara jumlah fraksi serat waru terhadap kekerasan sampel pada suhu $25^{\circ} \mathrm{C}$.
Dari grafik tersebut terlihat bahwa nilai kekerasan terbesar dimiliki oleh sampel dengan fraksi serat waru $4 \%$ yaitu sebesar 21,70 HV. Nilai kekerasan terkecil dimiliki oleh sampel dengan fraksi serat $12 \%$ yaitu sebesar 12,6 HV. Berdasarkan grafik dapat diketahui bahwa nilai kekerasan semakin turun akibat komposisi serat waru yang semakin banyak.

Serat memiliki sifat keuletan (ductility) yang lebih besar dibanding komposisi lain dalam komposit. Serat waru yang ditambahkan ke dalam komposit akan menambah sifat ulet dan menurunkan nilai kekerasannya dari komposit.

Nilai kekerasan sampel pada suhu $150^{\circ} \mathrm{C}$ dan $300^{\circ} \mathrm{C}$ berbeda untuk setiap variasi fraksi serat waru. Grafik yang diperoleh tidak menunjukkan korelasi yang jelas antara fraksi serat waru terhadap nilai kekerasan.

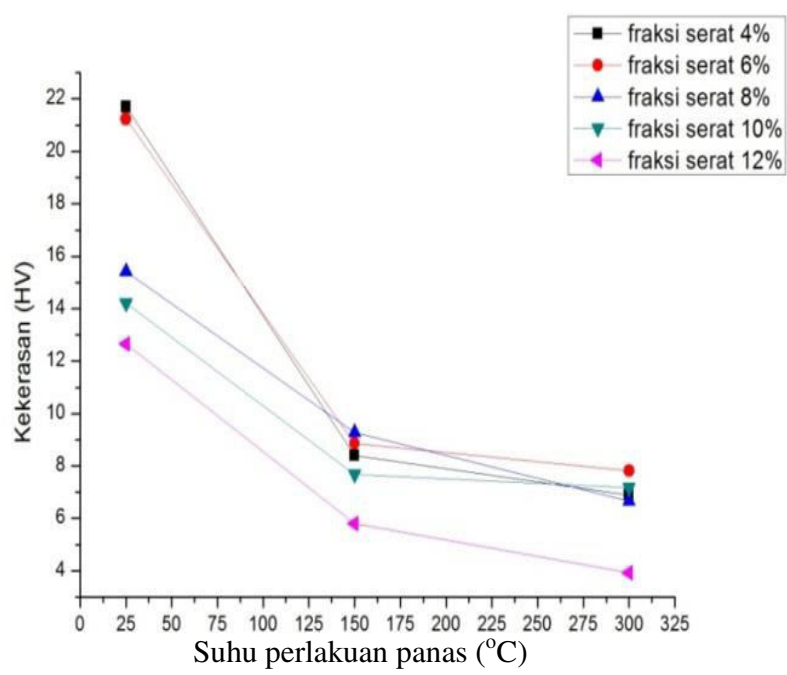

Gambar 7. Grafik hubungan suhu perlakuan panas terhadap nilai kekerasan sampel.

Grafik hubungan antara variasi suhu terhadap nilai kekerasan setiap sampel ditunjukkan pada Gambar 7. Berdasarkan grafik tersebut dapat terlihat bahwa nilai kekerasan semua sampel mengalami penurunan untuk setiap kenaikan suhu. Nilai kekerasan dipengaruhi oleh beberapa faktor yaitu ukuran butir (grain), perlakuan panas, suhu, dan kondisi atmosfer. Pada suhu tinggi bahan lebih mudah mengalami retakan.

Proses pemanasan memberikan pengaruh terhadap nilai kekerasan sampel. Matriks yang digunakan sebagai pengikat pada komposit adalah jenis resin vinylester yang dapat terdegradasi di atas suhu $165^{\circ} \mathrm{C}$. Nilai densitas dari sampel pada variasi suhu $150^{\circ} \mathrm{C}$ mengalami penurunan akibat resin yang mulai terdegradasi. Terjadinya degradasi ini mengakibatkan kemampuan matriks untuk mengikat filler berkurang sehingga ketahanan komposit terhadap deformasi plastis juga berkurang dan nilai kekerasan turun. Penurunan nilai kekerasan juga terjadi pada sampel dengan variasi suhu $300^{\circ} \mathrm{C}$ akibat resin yang semakin terdegradasi.

\section{B. Hasil Pengujian Densitas}

Pengujian nilai densitas dilakukan dengan prinsip Archimedes. Selain variasi fraksi serat waru juga diberikan 
variasi suhu perlakuan panas pada sampel yaitu $25^{\circ} \mathrm{C}, 150^{\circ} \mathrm{C}$, dan $300^{\circ} \mathrm{C}$. Hasil pengujian nilai densitas semua sampel dapat dilihat pada berikut.

Tabel 2.

Nilai densitas semua sampel

\begin{tabular}{ccc}
\hline \hline Fraksi serat waru (\%) & Perlakuan panas $\left({ }^{\circ} \mathrm{C}\right)$ & Densitas $\left(\mathrm{g} / \mathrm{cm}^{3}\right)$ \\
\hline \multirow{2}{*}{4} & 25 & 19,791 \\
& 150 & 19,404 \\
& 300 & 18,668 \\
\multirow{2}{*}{6} & 25 & 19,521 \\
& 150 & 19,006 \\
& 300 & 16,488 \\
\multirow{2}{*}{8} & 25 & 19,209 \\
& 150 & 17,938 \\
& 300 & 17,555 \\
10 & 25 & 19,040 \\
& 150 & 17,889 \\
& 300 & 17,280 \\
\multirow{2}{*}{12} & 25 & 19,028 \\
& 150 & 18,131 \\
& 300 & 17,781 \\
\hline \hline
\end{tabular}

Dari hasil yang diperoleh, terlihat bahwa nilai densitas sampel dipengaruhi oleh jumlah fraksi serat waru. Nilai densitas dari suatu bahan komposit dipengaruhi oleh densitas dari bahan penyusunnya. Walaupun bahan komposit telah terbentuk atas penyusunnya dengan struktur homogen secara makroskopis, tetapi sifat dari setiap komponen masih berpengaruh terhadap sifat komposit yang terbentuk

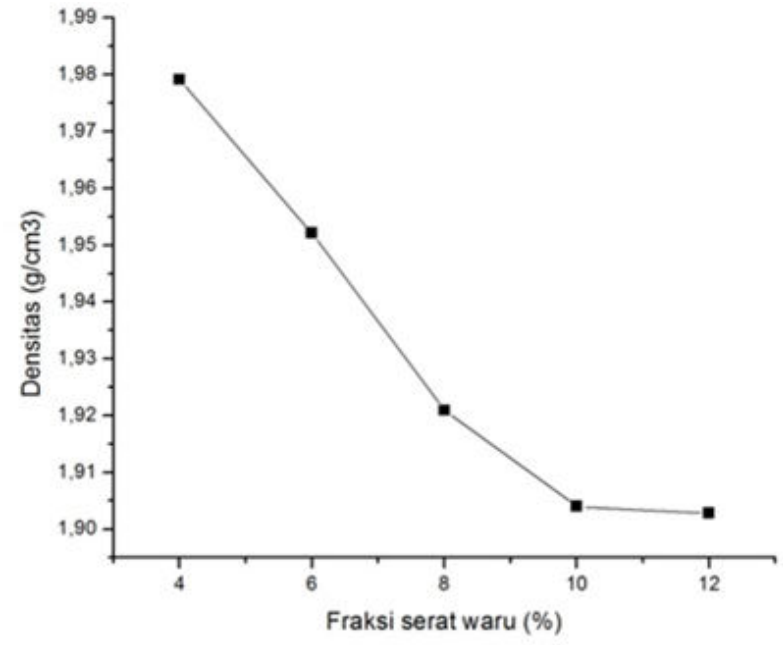

Gambar 8. Grafik hubungan fraksi serat waru terhadap nilai densitas pada suhu perlakuan panas $25^{\circ} \mathrm{C}$.

Pada Gambar 4.5 dapat terlihat hubungan antara fraksi serat waru dengan nilai densitas pada suhu $25^{\circ} \mathrm{C}$. Berdasarkan grafik dapat terlihat bahwa nilai densitas sampel cenderung turun untuk setiap kenaikan jumlah fraksi serat waru. Nilai densitas terbesar dimiliki sampel dengan fraksi serat waru $4 \%$ yaitu sebesar $1,9791 \mathrm{~g} / \mathrm{cm}^{3}$. Nilai ini kemudian turun menjadi 1,9521 $\mathrm{g} / \mathrm{cm}^{3}$ saat fraksi serat waru 6\%. Pada sampel dengan fraksi serat waru $8 \%, 10 \%$, dan $12 \%$ nilai densitas semakin turun.

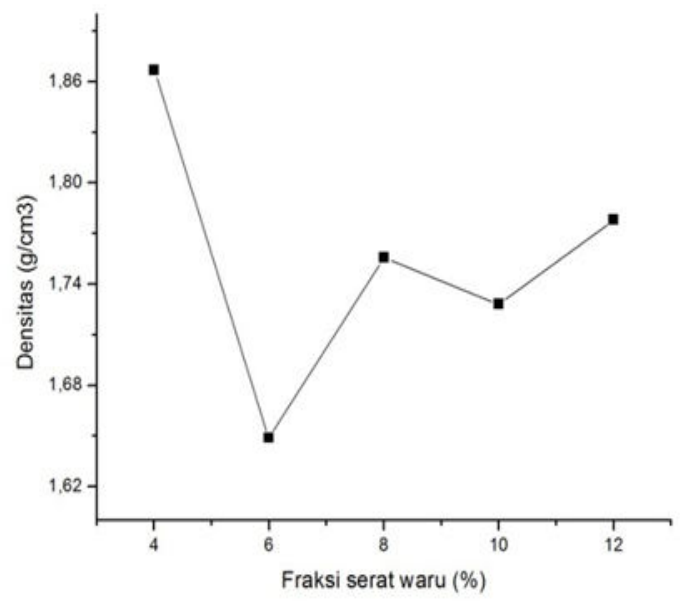

Gambar 9. Grafik hubungan fraksi serat waru terhadap nilai densitas pada suhu perlakuan panas $150^{\circ} \mathrm{C}$.

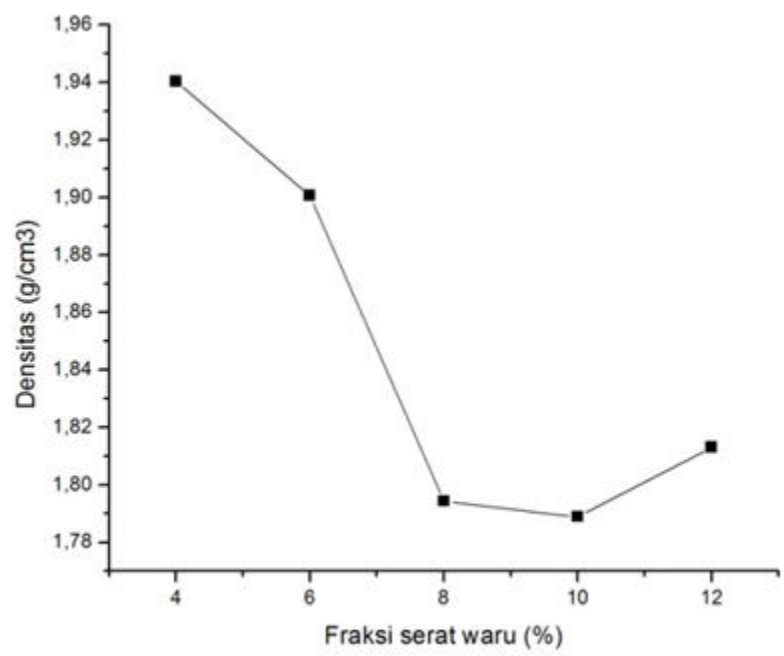

Gambar 10. Grafik hubungan fraksi serat waru terhadap nilai densitas pada suhu perlakuan panas $300^{\circ} \mathrm{C}$.

Massa jenis dari serat waru lebih kecil jika dibandingkan dengan massa jenis penyusun komposit lainnya. Karena itu saat komposisi serat waru dalam komposit semakin banyak, maka densitas dari komposit juga semakin berkurang. Peningkatan jumlah fraksi serat waru juga meningkatkan porositas pada komposit karena nilai porositas berbanding terbalik terhadap densitas.

Pada suhu $150^{\circ} \mathrm{C}$ dan $300^{\circ} \mathrm{C}$ nilai densitas berbeda untuk setiap variasi fraksi serat waru. Berdasarkan grafik pada Gambar 9 dan Gambar 10 terlihat bahwa tidak terdapat korelasi yang jelas antara fraksi serat waru terhadap nilai densitas.

Selain komposisi serat, densitas dari sampel juga dipengaruhi oleh suhu perlakuan panas yang diberikan. Hubungan antara suhu perlakuan panas terhadap nilai densitas ditunjukkan oleh grafik pada Gambar 4.8. 


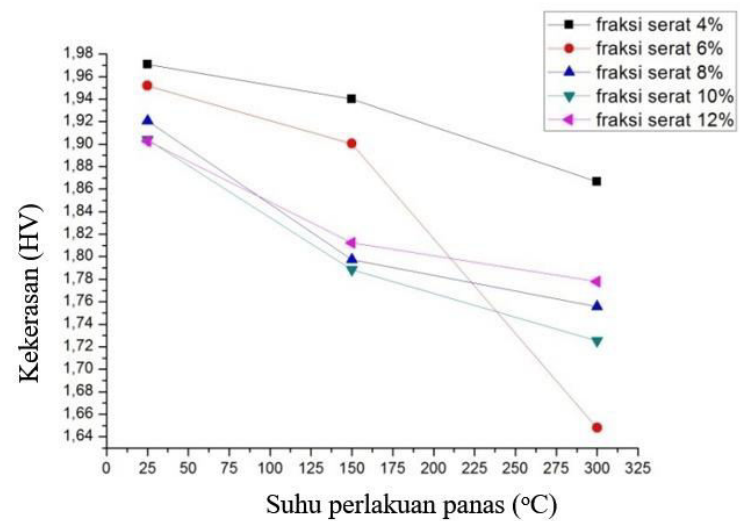

Gambar 11. Grafik hubungan suhu perlakuan panas terhadap nilai densitas sampel.

Pada setiap kenaikan suhu perlakuan panas nilai densitas sampel mengalami penurunan. Namun laju penurunan nilai densitas masing-masing sampel terhadap kenaikan suhu tidak sama. Nilai densitas yang paling stabil adalah densitas sampel dengan fraksi berat serat waru $4 \%$. Penambahan bahan berbasis polimer pada komposit dapat meningkatkan porositas dan mengurangi densitas pada suhu tinggi. Hal ini disebabkan karena pada suhu tinggi bahan polimer dapat menguap. Suhu sintering juga memengaruhi banyaknya pori yang terbentuk dalam bahan.

Nilai densitas terbesar untuk setiap variasi suhu dimiliki sampel dengan fraksi serat waru $4 \%$. Sementara nilai densitas terkecil untuk variasi suhu $150^{\circ} \mathrm{C}$ dimiliki sampel dengan fraksi serat waru $12 \%$ dan untuk variasi suhu $300^{\circ} \mathrm{C}$ dimiliki sampel dengan fraksi serat waru 6\%.

\section{Hasil Pengujian Koefisien Gesek}

Untuk mengetahui kemampuan pengereman dilakukan pengujian koefisien gesek. Aplikasi kampas rem kereta api adalah untuk menghentikan laju kereta api dengan memperlambat putaran roda. Pada saat bekerja, kampas rem akan bergesekan dengan disc brake yang terbuat dari baja yang terletak di as roda kereta api. Karena itu pengujian dilakukan untuk mendapatkan nilai koefisien gesek antara permukaan kampas rem dan baja.

Tabel 3.

Nilai koefisien gesek semua sampel

\begin{tabular}{cc}
\hline \hline Fraksi serat waru (\%) & Koefisien gesek \\
\hline 4 & 0,1406 \\
6 & 0,1719 \\
8 & 0,1760 \\
10 & 0,1779 \\
12 & 0,1899 \\
\hline \hline
\end{tabular}

Nilai koefisien gesek yang diperoleh berbeda untuk setiap variasi fraksi berat serat waru. Hubungan antara besarnya fraksi berat serat waru dengan nilai koefisien gesek ditunjukkan oleh grafik pada Gambar 12. Dari grafik tersebut terlihat bahwa semakin besar fraksi berat serat waru maka semakin besar nilai koefisien gesek. Komposisi serat waru menambah kekasaran pada kontur permukaan sampel sehingga meningkatkan nilai koefisien gesek.

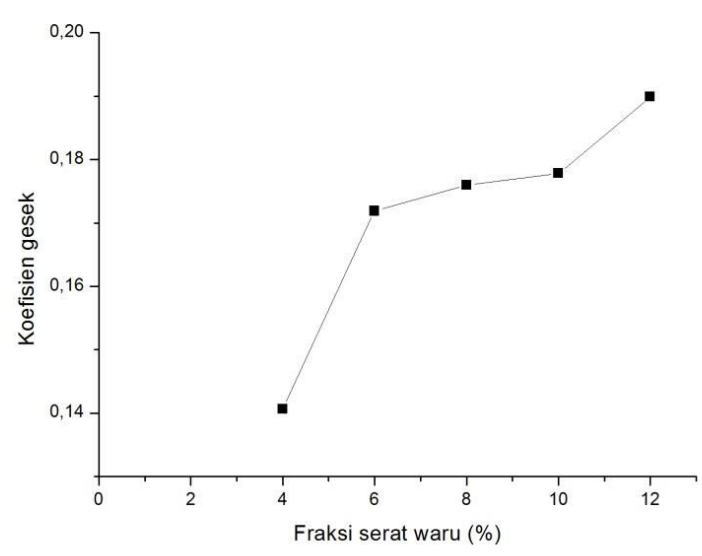

Gambar 12. Grafik hubungan fraksi serat waru terhadap nilai koefisien gesek.

Nilai koefisien gesek terbesar dimiliki oleh sampel dengan fraksi serat waru $12 \%$ yaitu sebesar 0,1899 . Nilai koefisien gesek terkecil dimiliki oleh sampel dengan fraksi serat waru $4 \%$ yaitu sebesar 0,1406 .

Serat memiliki sifat permukaan yang kasar. Banyaknya komposisi serat dalam suatu bahan kampas rem komposit akan menambah luasan serat pada permukaan yang berinteraksi dengan disc brake. Nilai koefisien gesek antara pemukaan kampas rem dengan disc brake akan meningkat. Besarnya koefisien gesek dapat mengurangi beban pengereman sehingga komponen-komponen rem lebih awet.

\section{Hasil Pengujian Keausan}

Untuk mengetahui ketahanan bahan terhadap abrasi dilakukan uji keausan. Pengujian keausan dilakukan dengan alat tribometer pin on disc menggunakan beban $1,4685 \mathrm{~kg}$ dan kecepatan putar piringan pengaus $300 \mathrm{rpm}$ selama 20 menit untuk setiap variasi sampel. Volume sampel yang berkurang akibat pengausan dicatat dan dilakukan perhitungan dengan persamaan 3.2. Hasil pengujian keausan untuk semua sampel dapat dilihat pada Table 4.

Berdasarkan Tabel 4 dapat diketahui bahwa nilai keausan setiap sampel berbeda. Nilai keausan semakin besar dengan bertambahnya fraksi serat waru pada sampel. Grafik pada Gambar 4.10 menunjukkan hubungan antara jumlah fraksi serat waru terhadap nilai keausan. Grafik tersebut menunjukkan bahwa nilai keausan berbanding lurus dengan jumlah fraksi serat waru. Semakin besar fraksi serat waru maka semakin besar nilai keausan.

Tabel 4.

Nilai keausan semua sampel

\begin{tabular}{ccccc}
\hline \hline $\begin{array}{c}\text { Fraksi serat } \\
(\%)\end{array}$ & $\begin{array}{c}\text { Volume } \\
\text { berkurang } \\
\left(\mathrm{cm}^{3}\right)\end{array}$ & $\begin{array}{c}\text { Massa } \\
\text { beban } \\
(\mathrm{kg})\end{array}$ & $\begin{array}{c}\text { Jarak } \\
\text { pengausan } \\
(\mathrm{cm})\end{array}$ & $\begin{array}{c}\text { Keausan } \\
\left(\times 10^{-7}\right. \\
\left.\mathrm{cm}^{2} / \mathrm{kg}\right)\end{array}$ \\
\hline 4 & 0,015 & 1,4685 & $622 \times 10^{3}$ & 0,45 \\
6 & 0,026 & 1,4685 & $622 \times 10^{3}$ & 0,75 \\
8 & 0,040 & 1,4685 & $622 \times 10^{3}$ & 1,2 \\
10 & 0,050 & 1,4685 & $622 \times 10^{3}$ & 1,5 \\
12 & 0,065 & 1,4685 & $622 \times 10^{3}$ & 2,0 \\
\hline \hline
\end{tabular}




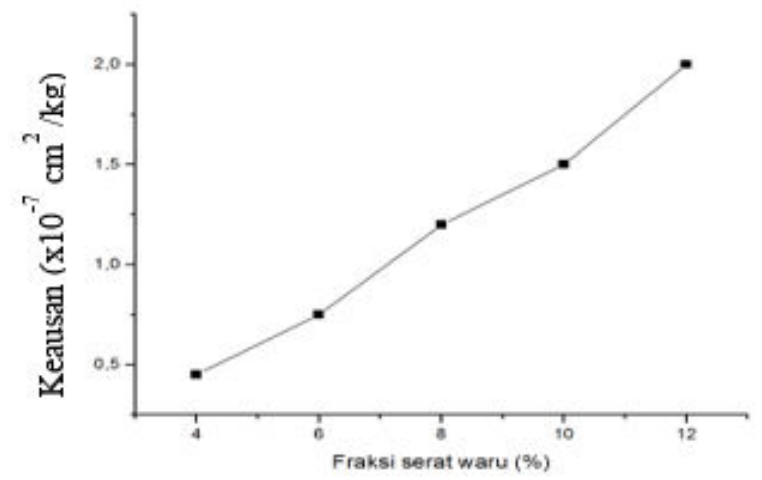

Gambar 13. Grafik hubungan fraksi serat waru terhadap keausan

Nilai keausan terbesar dimiliki sampel dengan fraksi serat waru $4 \%$ yaitu sebesar $0,45 \times 10^{-7} \mathrm{~cm}^{2} / \mathrm{kg}$. Nilai keausan terkecil dimiliki sampel dengan fraksi serat waru $12 \%$ yaitu sebesar $2,0 \times 10^{-7} \mathrm{~cm}^{2} / \mathrm{kg}$. Semakin kecil nilai keausan maka akan ketahanan bahan terhadap abrasi akan semakin besar dan kampas rem semakin awet.

Hasil dari pengujian yang telah dilakukan menujukkan hubungan antara pengaruh fraksi berat serat waru terhadap semua sifat mekanik kampas rem. Pada suhu ruang, peningkatan fraksi serat waru menurunkan nilai kekerasan kampas rem. Hubungan nilai kekerasan dan densitas menunjukkan bahwa semakin kecil nilai densitas maka nilai kekerasan juga semakin berkurang. Hal ini terjadi karena pada saat nilai densitas rendah maka porositas akan meningkat sehingga kemampuan bahan untuk menahan deformasi plastis akan berkurang dan nilai kekerasan juga menurun. Bahan yang memiliki kekerasan rendah akan lebih mudah mengalami abrasi. Hal ini terbukti dengan nilai keausan sampel kampas rem yang semakin bertambah saat nilai kekerasan berkurang. Sedangkan koefisien gesek dipengaruhi oleh jumlah fraksi serat waru yang menentukan kekasaran permukaan sampel kampas rem.

\section{KESIMPULAN}

Berdasarkan penelitian yang telah dilakukan, diperoleh kesimpulan sebagai berikut:

1. Kampas rem kereta api komposit non asbestos berpenguat serat waru telah berhasil dibuat dengan variasi fraksi serat waru $4 \%, 6 \%, 8 \%, 10 \%$, dan $12 \%$.
2. Pengaruh fraksi berat serat waru terhadap sifat mekanik kampas rem kereta api komposit non asbestos berpenguat serat waru adalah:

a. Nilai kekerasan terbesar dimiliki oleh sampel dengan fraksi serat waru $4 \%$ pada suhu $25^{\circ} \mathrm{C}$ yaitu sebesar 21,70 HV. Nilai kekerasan terkecil dimiliki oleh sampel dengan fraksi berat $12 \%$ pada suhu $300^{\circ} \mathrm{C}$ yaitu sebesar 3,92 $\mathrm{HV}$.

b. Nilai densitas terbesar dimiliki oleh sampel dengan fraksi serat waru $4 \%$ pada suhu $25^{\circ} \mathrm{C}$ yaitu sebesar $1,9791 \mathrm{~g} / \mathrm{cm}^{3}$. Nilai densitas terkecil dimiliki oleh sampel dengan fraksi serat waru $6 \%$ pada suhu $300^{\circ} \mathrm{C}$ yaitu sebesar 1,6488 $\mathrm{g} / \mathrm{cm}^{3}$.

c. Nilai koefisien gesek terbesar dimiliki oleh sampel dengan fraksi serat waru $12 \%$ yaitu sebesar 1,8990. Nilai koefisien gesek terkecil dimiliki oleh sampel dengan fraksi serat waru $4 \%$ yaitu sebesar 0,1406 .

d. Nilai keausan terkecil dimiliki oleh sampel dengan fraksi serat waru $4 \%$ yaitu sebesar $0,45 \times 10^{-7} \mathrm{~cm}^{2} / \mathrm{kg}$, sedangkan nilai keausan terkecil dimiliki oleh sampel dengan fraksi serat waru $12 \%$ yaitu sebesar $2,0 \times 10^{-7} \mathrm{~cm}^{2} / \mathrm{kg}$.

\section{DAFTAR PUSTAKA}

[1] K. Reif, Fundamentals of Automotive and Engine Technology Standard Drives, Hybrid Drives, Brakes, Safety Systems. Germany: Springer Fachmedien Wiesbaden, 2014.

[2] F. D. Fitrianto and et al, "Pemanfaatan Serbuk Tongkol Jagung sebagai Alternatif Bahan Friksi Kampas Rem Non-Asbestos Sepeda Motor," Surakarta, 2013.

[3] V. K. Choo, Fundamentals of Composite Materials. USA: Knowen Academic Press Inc, 1990.

[4] W. D. Callister, Fundamentals of Materials Sciences and Engineering. USA: John Wiley and Sons, 2001.

[5] A. K. Mohanty, Natural Fibers, Biopolymers, and Biocomposites. USA: Taylor and Francis Group, 2005.

[6] V. Zharvan and et al, "Studi Struktur Mikro dan Kuat Lentur Komposit Geopolimer Serat Bambu dengan Temperatur Curing Berbeda," J. Fis. dan Apl., 2013.

[7] A. Nurudin, "Potensi Pengembangan Komposit Berpenguat Serat Kulit Waru (Hibiscus tiliaceus) Kontinyu Laminat sebagai Material Pengganti Fiberglass pada Pembuatan Lambung Kapal,” 2016.

[8] A. Prasetyo and et al, "Pengaruh Waktu Perendaman Serat Kulit Pohon Waru (Hibiscus tiliaceus) pada Air Laut Terhadap Struktur Mikro dan Kekuatan Tarik," Semarang, 2016. 